\title{
Role of Tube Exchanger Catheter and Oral Endoscope for Intubation in an Unanticipated Difficult Airway in Patient with Carcinoma Larynx
}

\author{
Pramod Gupta, Madhu and Mukesh \\ Department of Anaesthesiology and Critical Care Safdarjang Hospital \& Vardhman Mahavir Medical College New Delhi, \\ India
}

Received: November 29, 2017; Accepted: December 15, 2017; Published: January 02, 2018

*Corresponding author: Dr. Pramod Gupta, Department of Anaesthesiology and Critical Care Safdarjang Hospital \&Vardhman Mahavir Medical College New Delhi, India, E-mail: guptapdnb@yahoo.co.in

\begin{abstract}
An unanticipated difficult airway is a great challenge for an anaesthesiologist especially when general anesthesia and $\mathrm{N}-\mathrm{M}$ blocking agent has already being administered at the time of induction. In this case of carcinoma larynx, on laryngoscopy vocal cord chink was found to be v small and it was impossible to intubate the trachea even with smaller ETT .We used a ventilating tube exchanger catheter in emergency situation to oxygenate and ventilate the lungs and with the help of zero degreeoral endoscope, which was available with ENT surgeons, we could manage to intubate trachea with ETT size 6.5 cuff tube and got biopsy done.
\end{abstract}

Keywords: Ca Larynx; Difficult Intubation; Tube Exchange Catheter; Endoscope; Intubation;

\section{Case Report}

A case report of, 55 yrs old male with height of $165 \mathrm{~cm}$ and weight $60 \mathrm{~kg}$ who was posted for biopsy of a growth in the larynx. There was no co-morbid disease and the lab investigations, $\mathrm{x}$-ray chest and electrocardiogram were within normal limits. The patient was noted to have a Mallampati's Class - 1 airway with good mouth opening.

Since there was a long waiting queue for CT of elective cases and the ENT surgeon did not want to wait for the case of CA Larynx and wanted to take only biopsy. And since the patient was asymptomatic, the ENT surgeon did not anticipate difficult intubation and also the patient was uncooperative for indirect laryngoscopy. Thus CT and indirect laryngoscopy were not done. Emergency cart was kept ready including tracheostomy set, before starting the case.

On the night prior to surgery, patient was premedicated with tablet Alprax $0.25 \mathrm{mg}$ orally. On the operative table, all the standard monitors were attached. The patient was noted to have Pulse rate of $82 / \mathrm{min}$, Blood pressure of $120 / 84 \mathrm{mmHg}$, Respiratory rate of $12 / \mathrm{min}$ and $\mathrm{SpO}_{2}$ of $98 \%$ on air. An intravenous catheter of size 20 was put in left hand, normal saline was started and the patient was pre medicated with injection midazolam $1 \mathrm{mg}$ iv.

After 5 mins of preoxygenation, the patient was induced with iv fentanyl (75 $\mu \mathrm{g})$, propofol $(1 \mathrm{mg} / \mathrm{kg})$ and atracurium $(0.5$ $\mathrm{mg} / \mathrm{kg}$ ). On larygoscopy, it was observed that the growth was covering more than $3 / 4^{\text {th }}$ of the circumference of the glottic area. There was a very small chink available to pass an endotracheal tube of size 5. As the indirect laryngoscopy had not been done in this patient, the airway condition was unanticipated for us. In this emergency, we used a ventilating Hudson Sheridan Jettex tracheal tube exchanger, (OD $4.8 \mathrm{~mm}$ ) which was passed through the glottic opening to oxygenate /ventilate the patient with $100 \% \mathrm{O}_{2}$. The minimum size of the endotracheal tube that can be railroaded over this exchanger is size 6.5 onwards. End tidal $\mathrm{CO}_{2}$ was monitored by attaching the tube exchanger via a 3 way cannula to $\mathrm{ETCO}_{2}$ sampling line.

Surgeons were requested to visualize the glottic opening and growth using the endoscope (Hopskin's 0 o, 4 mm diameter, length $20 \mathrm{~cm}$, which was used to focus light at the laryngeal inlet) since the Neuromuscular blocking agent was already given and the patient was well maintained on ventilation with $\mathrm{SpO}_{2}$ of $97 \%$ and $\mathrm{EtCO}_{2}$ of $28 \mathrm{mmHg}$. When the endoscope was placed near the larynx to visualize the glottic area, it was observed that the endoscope could lift the growth slightly, the glottic chink increased as a result and there was a possibility of passing an endotracheal tube size 6.5 into the trachea. Endotracheal tube size 6.5 was slowly railroaded over a tube exchanger. Chest expansion and end tidal $\mathrm{CO} 2$ were checked. The tube was then fixed and airway was secured. General anaesthesia was maintained with $\mathrm{O}_{2}: \mathrm{N}_{2} \mathrm{O}(50 \%: 50 \%)$ with $0.8 \%$ Isoflurane and IPPV was given through closed circuit, supplemental doses of atracurium were administered when required. (Figure 1)

After the biopsy was taken and homeostasis was achieved, the N-M blocking agent was reversed with neostigmine $(2.5$ $\mathrm{mg}$ ) and glycopyrrolate $(0.4 \mathrm{mg})$, after watching for signs of complete neuromuscular blockade reversal, tube exchanger was reintroduced via endotracheal tube and the patient was oxygenated with $100 \% 02$ and the end tidal CO2 was monitored continuously. The endotracheal tube was removed over the tube exchanger and patient was monitored for 10 minutes aft with the exchanger in situ. The tube exchanger was removed when the 


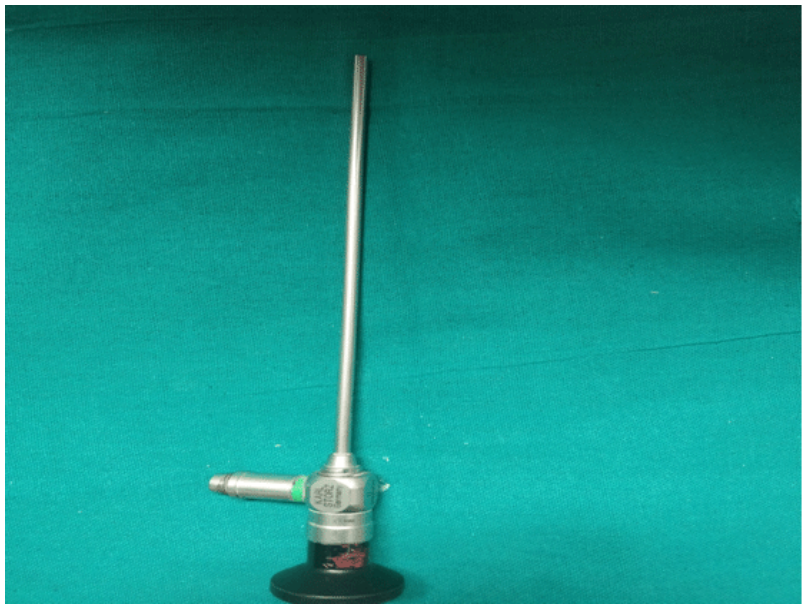

Figure 1: Hopskin's zero degree Endoscope

patient was fully awake and alert. The patient was shifted to the post operative care unit for observation and monitoring.

\section{Discussion}

In the mentioned case, ON LARYNGOSCOPY, the Glottic opening was just visible. An Endotracheal tube of size no. 5 was tried to intubate the trachea, but the growth was coming onto the side of glottis. Since the case was suspected to be a case of carcinoma larynx which is supposed to be very friable in nature so it was not possible to intubate the trachea without causing trauma to the growth. Simultaneously it was very necessary to oxygenate and ventilate the patient; tube exchange catheter was immediately made available and was introduced into the trachea to oxygenate the patient.

Hudson tube exchanger has outer diameter of $4.8 \mathrm{~mm}$ so endotracheal tube which could be railroaded over it is of size 6.5 to $10 \mathrm{~cm}$. Whereas Hopkin oral /nasal endoscope 0 degree is a straight metallic tube which gives focused illumination at larynx and it has already replaced indirect laryngoscopy. It has outer diameter of $3 \mathrm{~mm}$ which made us easy to intubate the trachea with MLS tube of no 5 it also slightly lifted the growth to give a better view. (Figure 2)

Tube exchanger does not allow endotracheal tube of size $5 \mathrm{~mm}$ to be rail roaded over it so it had to be removed before endoscopy and finally with help of endoscope tracheal intubation with (6.5 cuff tube) was made possible within seconds. It is manufactured by Hudson Respiratory Care, USA. It has openings at proximal and distal ends. It has markings from 18 to $32 \mathrm{cms}$.

\section{Frova Intubating Introducer}

It is a blunt, curved tip catheter with distal side ports for oxygenation. It is available in sizes Fr 8, 14 G with lengths of 35 and $65 \mathrm{cms}$ respectively. Catheter has internal diameter of 1.6 $\mathrm{mm}$ and $3 \mathrm{~mm}$ and can pass tubes of size 3 and 6 over it.

\section{Cook airway exchange catheter}

It has a soft tip with extra firm body that makes it atraumatic as an airway device. It has a distal side port for oxygenation,

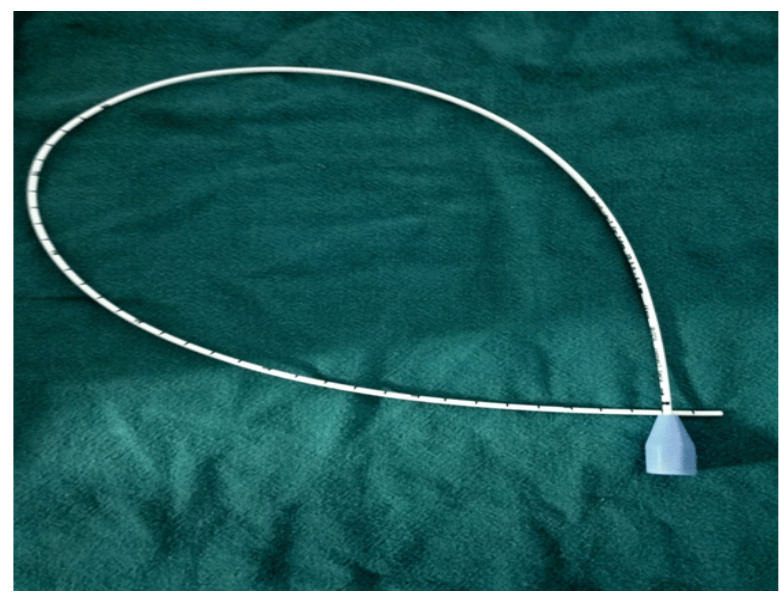

Figure 2: Hudson Tube Exchange Catheter

tillength of $10 \mathrm{cms}$. It has an internal diameter $2.3 \mathrm{~mm} / 3 \mathrm{~mm}$. The advantage is that it can be used to place smaller tubes of size 4 and 5.

\section{Aintree intubation catheter}

It is available in size of FrG with size 19 with length of $56 \mathrm{cms}$ internal diameter $4.7 \mathrm{~mm}$, tube of size 7 or larger can be passed over it. (Tables 1-4)

Table 1: Hudson tube exchange Catheter: It has markings from 18 to $32 \mathrm{cms}$. It can be easily used prior to tracgeal extubation.

\begin{tabular}{|c|c|c|c|c|}
\hline Size & $\begin{array}{c}\text { Catheter } \\
\text { length }(\mathrm{cm})\end{array}$ & $\begin{array}{c}\text { Catheter ID } \\
(\mathrm{mm})\end{array}$ & $\begin{array}{c}\text { For exchange of } \\
\text { ETT with ID }\end{array}$ & $\begin{array}{c}\text { Includes } \\
\text { adapter type }\end{array}$ \\
\hline 19 & 56 & 4.0 & 6.5 or larger & $\begin{array}{c}15 \mathrm{~mm} \text { and } \\
\text { luer lock }\end{array}$ \\
\hline
\end{tabular}

Table 2: Frova Intubating Introducer: It is a blunt, curved tip catheter with distal side ports for oxygenation.

\begin{tabular}{|c|c|c|c|}
\hline $\begin{array}{c}\text { FrovaIntubating } \\
\text { cathether SIZE }\end{array}$ & Iength & $\begin{array}{c}\text { For placement of } \\
\text { ETT with ID mm }\end{array}$ & $\begin{array}{c}\text { Includes adapter } \\
\text { type }\end{array}$ \\
\hline $8 \mathrm{G} \mathrm{FG}$ & $35 \mathrm{~cm}$ & $\begin{array}{c}3 \text { or larger Id } \\
1.6 \mathrm{~mm}\end{array}$ & $\begin{array}{c}15 \mathrm{~mm} \text { and Luer } \\
\text { lock }\end{array}$ \\
\hline $14 \mathrm{G} \mathrm{FG}$ & $65 \mathrm{~cm}$ & $\begin{array}{c}6 \text { or larger ID } \\
3 \mathrm{~mm}\end{array}$ & $\begin{array}{c}15 \mathrm{~mm} \text { and Luer } \\
\text { lock }\end{array}$ \\
\hline
\end{tabular}

All these exchangers have facility for jet ventilation and are radio-opaque.

Since Hudson exchanger has inner diameter of $4 \mathrm{~mm}$, it is less traumatic. Moreover being Smaller in size can be passed along sidewall of vocal cord even if the laryngeal growth is at inlet of larynx.

Gerard Mayers used cook airway exchange catheter in a case of difficult extubation. It is a long flexible hollow tube designed as tube exchanger, was used in morbidly obese patient as a bridge to extubation. Cook airway exchange catheter has $15 \mathrm{~mm}$ external diameter and has facility for jet ventilation. The tube exchanger provided the reassurance of having a guide to facilitate awake or 
Table 3: Cook airway exchange catheter: It has a soft tip with extra firm body that makes it atraumatic device. It has a distal side port for oxygenation, till $10 \mathrm{cms}$.

\begin{tabular}{|c|c|c|c|c|}
\hline $\begin{array}{c}\text { Cook } \\
\text { airway } \\
\text { Catheter } \\
\text { (Fr) }\end{array}$ & $\begin{array}{c}\text { Catheter } \\
\text { length (cm) }\end{array}$ & $\begin{array}{c}\text { Catheter ID } \\
\text { (mm) }\end{array}$ & $\begin{array}{c}\text { For exchange } \\
\text { of ETT with } \\
\text { ID (mm) }\end{array}$ & $\begin{array}{c}\text { Includes } \\
\text { adapter } \\
\text { type }\end{array}$ \\
\hline 8 & 45 & 1.6 & 3 or larger & $\begin{array}{c}15 \mathrm{~mm} \\
\text { and Luer } \\
\text { lock }\end{array}$ \\
\hline 11 & 83 & 2.3 & 4 or larger & $\begin{array}{c}15 \mathrm{~mm} \\
\text { and Luer } \\
\text { lock }\end{array}$ \\
\hline 14 & 83 & 3 & 5 or larger & $\begin{array}{r}15 \mathrm{~mm} \\
\text { and Luer } \\
\text { lock }\end{array}$ \\
\hline 19 & 83 & 3.4 & 7 or larger & $\begin{array}{r}15 \mathrm{~mm} \\
\text { and Luer } \\
\text { lock }\end{array}$ \\
\hline & & & & \\
\hline
\end{tabular}

Table 4: Aintree intubation catheter: Used for assisted fiberoptic intubation and for uncomplicated, atraumatic endotracheal tube exchange.

\begin{tabular}{|c|c|c|c|c|}
\hline size & $\begin{array}{c}\text { Catheter } \\
\text { length }(\mathrm{cm})\end{array}$ & $\begin{array}{c}\text { Catheter } \\
\text { ID }(\mathrm{mm})\end{array}$ & $\begin{array}{c}\text { For exchange } \\
\text { of ETT with } \\
\text { ID }(\mathrm{mm})\end{array}$ & $\begin{array}{c}\text { Includes adapter } \\
\text { type }\end{array}$ \\
\hline 19 & 56 & 4.7 & 7 or larger & $\begin{array}{c}15 \mathrm{~mm} \text { and Luer } \\
\text { lock }\end{array}$ \\
\hline
\end{tabular}

assisted re intubation or a way to achieve jet ventilation in the event of developing hypoxemia [1].

Modified Ventilating Tube exchanger is used to facilitate tracheal intubation using Glidoscope in patients with limited mouth opening. This tube changer has diameter of $1.5 \mathrm{~mm}$ at its tip and six side ports with diameter of $1 \mathrm{~mm}$ on the distal $5 \mathrm{cms}$. A stiff metal stylet is also available with it [2].

Problems do occur using airway exchange catheter i.e. they are potentials for traumatic tissue damage [3].

The use of indwelling catheters, bougies to facilitate endotracheal intubation is well appreciated but these catheters are of larger outer diameters, made for bigger tubes [4].

Majority of time diagnosis of ca laryngx can be made through complete history and examination but CT and ultrasound are supposed to be more specific for the determination of nodal disease [5].
Udomtecha D used airway tube exchanger as primary intubation in obese patients [6].

The indwelling airway exchange catheter increases the first pass success rate with known or suspected difficult airways as studied by Mort TC [7].

Hollow exchange airway catheter can be used prior to tracheal extubation of adult patient who had risk of difficult tracheal reintubation [8].

\section{Conclusion}

A case of laryngeal growth should be considered as ancipated difficult airway. It should be taken up only after complete investigations i.e. X-ray neck, CT, oral endoscopy with camera \{which is been only recently made available and has replaced indirect laryngoscopy,\} Avoid n-m blocking agent ,if you are not sure about intubation, until the vocal chord /full growth is vistualised, On check laryngoscopy after giving propofol. However plan in advance, keep airway kit ready, including drugs for local anesthesia, stylet, bougie, smaller tubes, tube exchanger, fiberoptic bronchoscope adult and pedraitic and an expert anesthesiologist should be consulted beforehand.

\section{References}

1. Mayers G, McDougle L. Use of the cook airway exchange catheter in bridging the potentially difficult extubation -a case report. AANAjournal.2002;70(4):275-278.

2. DeLima L, Bishop M. Lung laceration after tracheal extubation over a plastic tube changer. Anesth Analg. 1991; 73:350-351.

3. Smith CE, Michaels E. Tracheal intubation using the gum bougie in an adult patient with epiglottitis. Am J Anesthesiol. 2001;28:98-100.

4. Nolan JP, Wilson ME. Orotracheal intubation in patients with cervical spine injuries. An indication for the gum elastic bougie. Anesthesia. 1993;48:630-633.

5. Lochn B, Kunduk M, Andrew J. Advanced laryngeal cancer. In: Bailey head and neck surgery of otolarngology. 5th edition. 2014;124:19611962.

6. Udomtecha D. Airway tube exchanger techniques in morbidly obese patients. Anesthesiol Res Pract. 2012:220-230.

7. Mort TC. Continuous airway access for the difficult extubation: the efficacy of the airway exchange catheter. Anesth Analg. 2007;105(5):1357-1362. DOI: 10.1213/01.ane.0000282826.68646.a1

8. Loudermilk EP, Hartmannsgruber M, Stoltzfus DP, Langevin PB. A prospective study of the safety of tracheal extubation using a pediatric airway exchange catheter for patients with a known difficult airway. Chest. 1997; 111(6):1660-1665 